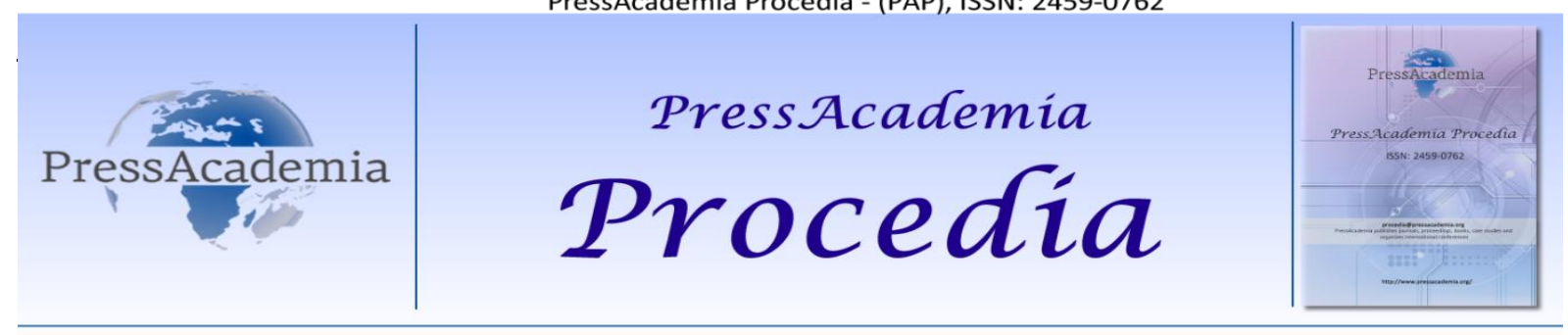

Global Business Research Congress (GBRC), May 24-25, 2017, Istanbul, Turkey.

\title{
AN ATTEMPT FOR APPLYING THE LCR AND CAR REQUIREMENTS TO TURKISH IRON AND STEEL SECTOR
}

\author{
DOI: 10.17261/Pressacademia.2017.407
}

PAP-GBRC-V.3-2017(22)-p.222-228

Ceren Turkmen ${ }^{1}$, Bucan Turkmen ${ }^{2}$

${ }^{1}$ Sakarya University.

${ }^{2}$ Turkiye Isbank.

\section{To cite this document}

Turkmen, N. C., B. Turkmen,(2017). An attempt for applying the ICR and car requirements to Turkish iron and steel sector.

PressAcademia Procedia (PAP), V.3, p.222-228

Permemant link to this document: $\underline{\text { http://doi.org/10.17261/Pressacademia.2017.407 }}$

Copyright: Published by PressAcademia and limited licenced re-use rights only.

\begin{abstract}
Iron and steel sector is one of the key determinants of a country's GDP and Industrial Production, both due to size of its volume and the strategic importance of its outputs. Due to high installation costs, it is quite costly to compensate capacity losses. Hence, the financial viability of the iron and steel sector, which is in the locomotive position, is critical for the continuity of intermediate goods supply and overall price volatility. The sector also comprises an important part of banking system total credit risk, so the measurement of the sector's "liquidity" capacity of the balance sheet and the resistance of the equity against possible shocks determines the overall credit quality. It is aimed that the Basel III liquidity and capital adequacy criteria which are applied to the financial institutions will be applied on the balance sheets of selected iron and steel sector companies, since the risks of the real sector constitute counterparty risk for financial sector firm balance sheets.
\end{abstract}

Keywords: LCR, CAR, lion and steel sector, Basel 3, liquidity regulation.

JEL Codes: G32, G28, L61

\section{INTRODUCTION}

The iron and steel industry consists of processes concerning iron and steel production by various methods and shaping according to the usage area. Since the iron and steel sector's outputs are the main inputs of construction, automotive, railway, defense and transport related sectors as well as manufacturing sub-sectors realizing the production of machinery and appliances, the sector is undoubtedly a locomotive sector for the overall economy. The worldwide increase in total economic activity and the rapid increase in demand for housing, automobiles and appliances due to economic growth, increases the world total steel production.

In this study; the performance criteria applied to the financial institutions are aimed to be used in real sector firms' balance sheets and profit and loss accounts, since the financial statement risks borne by the real sector constitute the counterparty risk in financial sector firms' balance sheets.

In other words, we aim to interpret laws, regulations and legislations in terms of liquidity and capital adequacy to which financial sector intuitions are subject, on sectoral basis and implement them to iron and steel sector financial tables. In this 
scope, interpreting financial fragility of retail sector will be interpreted according to international norms as recommended by Basel III.

This study is comprised of five sections. The second section, following the introduction, will focus on the opportunities and threats facing the iron and steel industry, after generally explaining the iron and steel industry's place in the world and in Turkey. In this sense, the second section can be accepted as constituting the basic focal points for the study. The fourth part is the presentation of the data and the methods used in the study. In the following section, the results and evaluations related to the analyzes done over the iron and steel sector financial tables will be expressed.

The main data source of the study is the financial tables of the iron and steel sector firms obtained from the Public Disclosure Platform (KAP).

\section{ECONOMIC BACKGROUND: THE GLOBAL AND TURKISH IRON AND STEEL SECTOR}

On the global scale, the capacity and production in the iron and steel sector have shown a rapid growth trend since the early 2000s, under the leadership of the People's Republic of China. Despite the production decline in 2008 and 2009, due to the the effects of the global economic crisis, the upward trend from 2010 onwards has been strong again. On the other hand the capacity increases was even not paused during the global crisis.

Figure 1 shows the world steel production in 1950-2015 (WSA, 2017). According to the figüre, the increasing trend in world steel production has become dominant especially in the 2000s. World crude steel production exceeded 1 billion tons for the first time in 2004 and rose to 1.6 billion tons in 2015. China, which has performed a large part of the registered capacity increase by itself, has become a determining country in iron and steel supply. Steel production increased $2.5 \%$ in the period $1995-2000,6.2 \%$ in the period $2000-2005,4.5 \%$ in the period $2005-2010$ and $2.5 \%$ in the period $2010-2015$.

Figure 1: Research Model

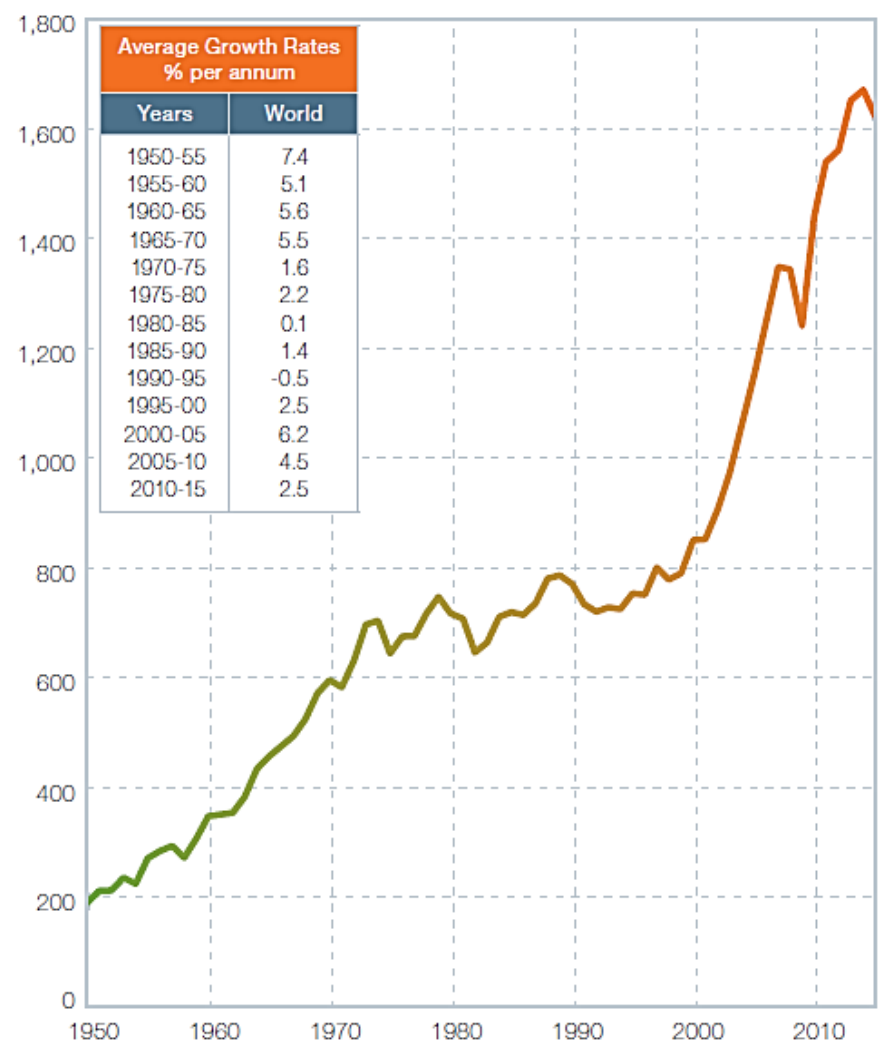


Table 1 shows the top 15 countries in steel production (WSA, 2017)

Table 1: Major Countries in Crude Steel Production (Million Tons)

\begin{tabular}{|l|c|c|c|c|}
\hline \multirow{2}{*}{ Country } & \multicolumn{2}{|c|}{2015} & \multicolumn{2}{c|}{2014} \\
\cline { 2 - 5 } & Rank & Tonnage & Rank & Tonnage \\
\hline China & $\mathbf{1}$ & 803.8 & $\mathbf{1}$ & 822.8 \\
\hline Japan & $\mathbf{2}$ & 105.2 & $\mathbf{2}$ & 110.7 \\
\hline India & $\mathbf{3}$ & 89.4 & $\mathbf{3}$ & 87.3 \\
\hline USA & $\mathbf{4}$ & 78.8 & $\mathbf{4}$ & 88.2 \\
\hline Russia & $\mathbf{5}$ & 70.9 & $\mathbf{5}$ & 71.5 \\
\hline South Korea & $\mathbf{6}$ & 69.7 & $\mathbf{6}$ & 71.5 \\
\hline Germany & $\mathbf{7}$ & 42.7 & $\mathbf{7}$ & 42.9 \\
\hline Brazil & $\mathbf{8}$ & 33.3 & $\mathbf{8}$ & 33.9 \\
\hline Turkey & $\mathbf{9}$ & 31.5 & $\mathbf{9}$ & 34.0 \\
\hline Ukraine & $\mathbf{1 0}$ & 23.0 & $\mathbf{1 0}$ & 27.2 \\
\hline Italy & $\mathbf{1 1}$ & 22.0 & $\mathbf{1 1}$ & 23.7 \\
\hline Taiwan, China & $\mathbf{1 2}$ & 21.4 & $\mathbf{1 2}$ & 23.1 \\
\hline Mexico & $\mathbf{1 3}$ & 18.2 & $\mathbf{1 3}$ & 18.9 \\
\hline Iran & $\mathbf{1 4}$ & 16.1 & $\mathbf{1 4}$ & 16.3 \\
\hline France & $\mathbf{1 5}$ & 15.0 & $\mathbf{1 5}$ & 16.1 \\
\hline
\end{tabular}

According to the table, the largest steel producer countries in 2015 are China (804 million tons), Japan (105 million tons) and India (89 million tons). Turkey is ninth in world crude steel production with production of 32 million tons in 2015.

The most important problem in the recent agenda of the sector is the global capacity surplus which is formed parallel to the rapid investments. Increased global crude steel consumption has fallen behind capacity and production improvements due to the ongoing effects of the global economic crisis, both in developed countries and developing countries. Hence there is an increase in global excess supply in the iron and steel sector. In this framework, the final product prices have fallen, henceforth the profit margins of the producers have also narrowed.

Table 2: Regional Distribution of World Steel Products Consumption (Million Tons)

\begin{tabular}{|l|c|c|c|c|c|c|c|}
\hline & $\mathbf{2 0 0 9}$ & $\mathbf{2 0 1 0}$ & $\mathbf{2 0 1 1}$ & $\mathbf{2 0 1 2}$ & $\mathbf{2 0 1 3}$ & $\mathbf{2 0 1 4}$ & $\mathbf{2 0 1 5}$ \\
\hline EU-28 & 121.2 & 146.4 & 156.7 & 140.3 & 142.0 & 149.1 & 153.3 \\
\hline Turkey & 18 & 23.60 & 26.9 & 28.5 & 31.3 & 30.8 & 34.4 \\
\hline Other Europe & 5.1 & 5.3 & 5.8 & 5.6 & 5.6 & 6.3 & 5.7 \\
\hline Russia & 24.8 & 36.7 & 41.5 & 42.8 & 43.3 & 43 & 39.4 \\
\hline Ukraine & 3.9 & 5.5 & 6.3 & 6.3 & 5.6 & 4.3 & 3.3 \\
\hline Other CIS & 7.2 & 7.2 & 7.5 & 8.6 & 9.8 & 8.8 & 7.3 \\
\hline NAFTA & 83.9 & 111.7 & 123.2 & 132.7 & 129.9 & 146.7 & 134.5 \\
\hline Central\&South America & 33.3 & 45.2 & 47.1 & 48.7 & 51.3 & 48.9 & 45.4 \\
\hline Africa & 31.9 & 28.4 & 29.4 & 32.9 & 36.4 & 37.4 & 39 \\
\hline MiddleEast & 46 & 48.7 & 51.3 & 50.7 & 51.7 & 53.5 & 53 \\
\hline Asia & 770 & 843.9 & 912.8 & 939.3 & 1020.6 & 1010.6 & 977.5 \\
\hline Oceania & 6 & 7.8 & 6.9 & 7.3 & 6.7 & 7.4 & 7.3 \\
\hline
\end{tabular}

Table 2 shows the regional distribution of world steel consumption (WSA,2017). Turkey's consumption of final steel products in the year 2015 included in Table 2 is 34.4 million tons. The majority of steel consumption is realized by the construction sector. Construction sector is followed by automotive, machinery-equipment and petroleum-natural gas sectors. While the construction sector is heavily using metal products and rebar, automotive sector widely uses cold / hot rolled products and galvanized products. 
When Turkey's consumption and production volumes of steel are compared from Table 1 and Table 2; it is observed that Turkey is a net importer of raw steel and steel related materials and/ or steel products. This situation is also observed in the list of steel trading countries which is given in Table 3 (WSA, 2017). Turkey is in the fifteenth place on the net steel importer list.

Table 3: Global Steel Trade (million tons)

\begin{tabular}{|l|c|l|l|c|l|}
\hline \multicolumn{3}{|c|}{ Net Exports } & \multicolumn{3}{c|}{ Net Imports } \\
\hline Country & Rank & Tonnage & Country & Rank & Tonnage \\
\hline China & $\mathbf{1}$ & 98.4 & USA & $\mathbf{1}$ & 26.5 \\
\hline Japan & $\mathbf{2}$ & 34.9 & Vietnam & $\mathbf{2}$ & 14.9 \\
\hline Russia & $\mathbf{3}$ & 25.3 & Thailand & $\mathbf{3}$ & 13.4 \\
\hline Ukraine & $\mathbf{4}$ & 16.9 & Indonesia & $\mathbf{4}$ & 9.4 \\
\hline Brazil & $\mathbf{5}$ & 10.5 & Mexico & $\mathbf{5}$ & 8.6 \\
\hline South Korea & $\mathbf{6}$ & 9.5 & Egypt & $\mathbf{6}$ & 7.7 \\
\hline Netherlands & $\mathbf{7}$ & 3.8 & Saudi Arabia & $\mathbf{7}$ & 6.4 \\
\hline Taivan, China & $\mathbf{8}$ & 3.7 & Algeria & $\mathbf{8}$ & 6.4 \\
\hline Austia & $\mathbf{9}$ & 3.2 & UAE & $\mathbf{9}$ & 6 \\
\hline Belgium & $\mathbf{1 0}$ & 3.1 & India & $\mathbf{1 0}$ & 5.7 \\
\hline Slovakia & $\mathbf{1 1}$ & 2.2 & Poland & $\mathbf{1 1}$ & 4.1 \\
\hline Luxembourg & $\mathbf{1 2}$ & 1.8 & Bangladesh & $\mathbf{1 2}$ & 4 \\
\hline Singapore & $\mathbf{1 3}$ & 1.7 & EU-28 & $\mathbf{1 3}$ & 6.9 \\
\hline Kazakhstan & $\mathbf{1 4}$ & 1.2 & Iran & $\mathbf{1 4}$ & 3.8 \\
\hline Finland & $\mathbf{1 5}$ & 0.9 & Turkey & $\mathbf{1 5}$ & 3.7 \\
\hline
\end{tabular}

More than half of Turkey's steel imports are from European Union (28) countries, followed by CIS countries and China (TCEB, 2016).

While, raw materials used in the iron and steel sector differ according to the production method, iron ore or scrap is used in production. From this aspect, Turkey is also dependent on imports in terms of raw materials. The sector is the net importer of almost all inputs. Both Turkish steel producers' disadvantages in terms of cost compared to their competitors, as well as the problems experienced in supplier countries, can lead to market losses.

Whether we are going to examine the sector in terms of raw materials, it can be easily stated that, iron ore is in a similar excess supply situation as in the steel sector. While iron ore prices are declining due to the decreasing demand due to economic crisis, it is estimated that if the demand for crude steel will not increase, the companies producing iron ore will have problems due to the piling stocks.

On the other hand, the tension between the Ukraine and Russia where the industry has been heavily importing scrap, has led to an increase in the cost of scrap imports and causes problems for Turkish producers to supply raw materials.

\section{DATA AND METHODOLOGY}

\subsection{Data}

Since this study is directly linked to the quality of quantitative data for analysis. The main data source of the study is the financial tables of the iron and steel sector firms obtained from the Public Disclosure Platform (KAP), thus, companies in the sample are subject to external auditing.

Within the scope of the study, 9 selected enterprises that directly produce steel or steel products were included from 14 enterprises listed on the BIST National Market in the iron and steel basic metal industry index. The sample list is given in Table 4. 
Table 4: Sample List

\begin{tabular}{|c|c|l|}
\hline Nr. & BIST Code & \multicolumn{1}{|c|}{ Company Name } \\
\hline $\mathbf{1}$ & ASCEL & Asil Celik Sanayi Ve Ticaret A.S. \\
\hline $\mathbf{2}$ & BRSAN & Borusan Mannesmann Boru Sanayi Ve Ticaret A.S. \\
\hline $\mathbf{3}$ & CELHA & Celik Halat Ve Tel Sanayii A.S. \\
\hline $\mathbf{4}$ & CEMTS & Cemtas Celik Makina Sanayi Ve Ticaret A.S. \\
\hline $\mathbf{5}$ & ERBOS & Erbosan Erciyas Boru Sanayii Ve Ticaret A.S. \\
\hline $\mathbf{6}$ & EREGL & Eregli Demir Ve Celik Fabrikaları T.A.S. \\
\hline $\mathbf{7}$ & IZMDC & Izmir Demir Celik Sanayi A.S. \\
\hline $\mathbf{8}$ & KRDMA, KRDMB, KRDMD & Kardemir Karabuk Demir Celik Sanayi Ve Ticaret A.S. \\
\hline $\mathbf{9}$ & OZBAL & Ozbal Celik Boru Sanayi Ticaret Ve Taahhut A.S. \\
\hline
\end{tabular}

\subsection{Method}

Before any analysis, in order to compute LCR and CAR, selected iron and steel sector financial table items should be harmonized with financial sector financial tables. In this scope, the following corrections are done by considering every company's footnotes individually. For obtaining sectoral results, arithmetic mean of the individual results was taken and inferences are tried to be made under the context of LCR and CAR requirements.

In the scope of the Regulation on Measurement and Assessment of Liquidity Adequacy of Banks (BRSA), net liquidity amount of iron and steel sector firms is found by calculating sum of highly liquid TRL and FX total of balance sheet items (will be stated as high liquid assets). High quality assets are calculated by summing current assets. Current assets such as maturity receivables beyond relevant maturity -including checks and bonds-, advances, taxes and any type of state receivables, semi-finished goods and raw materials -except the ones that do not have the direct selling opportunity in organized or unorganized markets, are not calculated as cash inflow, hence subtracted from high quality assets.

Inventories should be divided into parts according to the existence of direct re-sale opportunity in organized or unorganized markets and sales averages of inventories on item basis should be determined from past data. In this study, our supposition is that the inventories of iron and steel sector firms are all resalable as scrap with a loss of $20 \%$ in price, both in terms of raw materials, semi-finished goods or final products. On the other hand, parts of the inventory items whose direct sale opportunity does not exist in organized or unorganized markets are omitted from liquid cash inflow.

Parallel to Turkmen N.C. and Turkmen B. (2015), trade receivables and prepaid order advances are treated as the loans item in a bank's balance sheet and interpreted accordingly. In this scope, when determining the liquidity multiplier in relation to trade receivables, the decision should be made based on past payment performance and whether there is any guarantee taken. The multiplier where the trade linked is arisen from a relationship with an underlying bank letter of guarantee is accepted to be 1 . The multiplier for unguaranteed receivables is accepted as 0.5 for related parties and 0.75 for unrelated parties.

Since maturities of trade receivables is not known, multiplier for trade receivable turnover is determined according to average maturity calculation (1- (average maturity/365) and receivable quality and guarantee criteria should also be taken into account as mentioned above.

Receivables from tax office are not taken into account in calculations since they cannot be collected in cash except dissolution or export activity exist.

Inventories are treated as securities in the bank's balance sheet. In this scope, inventory items that can be identified as commodities are taken into account as cash inflow after depreciation allowances are set aside. The multiplier that can be used for liquidity calculation is accepted as $1-(1 /$ (net sales/average inventory stock)).

Short-term loans, trade payables and other short-term liabilities are simulated to deposit item in the bank's balance sheet and in this scope, interests of bank loans should be calculated as cash outflow. The sum of other short-term liabilities excluding advances and deposits is taken into account as cash outflow.

$60 \%$ of trade payables to relevant parties and $75 \%$ of the trade payables to non-relevant parties are taken into account as cash outflow excluding payables to financial companies or general expenses except goods purchases. Finally, a portion of pre-paid expenses corresponding to the period under analysis are taken into account. 
By using the abovementioned calculations, liquidity coverage ratio (LCR) is calculated by dividing high-quality liquid assets, to net short term payments.

When calculating capital adequacy ratio, firstly credit risk, market risk and operational risk should be measured. Instead of more sophisticated risk measuring methods, Standardized Approach to credit risk and Basic Indicator Approach to operational risk will be taken into account in this study for simplicity of applicability and for time and capital saving. Other interpretations and corrections on balance sheet items are given below.

Capital Adequacy Ratio is calculated as defined in the traditional Cook Ratio. In this scope, total equities in the numerator are deducted from undistributed profits ${ }^{1}$ and following assumptions are made for the total credit risk, market risk and operational risk in the denominator.

When we simulate the structure to bank balance sheet, "loan" item is calculated as summing trade payables, other payables, receivables monitored in fixed assets, advances made and pre-paid expenses.

Basic indicator approach was adapted in the calculation of operational risk. According to basic indicator approach, capital obligation is equal to $15 \%$ of the average of last three years' gross income. However, capital obligation is calculated by $5 \%$ more properly, due to sectoral reasons.

Total amount subject to market risk may be expressed as the sum of exchange rate risk, risk of value loss of fixed assets, inventory depreciation risk (in this scope, it can be evaluated as general market risk) and interest rate risk, stock market position risk and subsidiary risk.

Exchange rate risk will be taken into account as balance resulting from offsetting of the same currency assets and liabilities. The examination is made in the framework of exchange rate risk table in the footnotes of balance sheet and if the statement shows $10 \%$ increase or decrease in exchange rate, 10 times of this value is taken into account.

Total of fixed assets are taken into account for tangible asset value loss risk.

Inventory depreciation risk is a risk resulting from the decrease in market value of inventories. According to our abovementioned supposition, Inventory depreciation risk accepted as $20 \%$.

Interest rate risk is the difference between liquid assets subject to interest and liability items with floating interest rate, such as bank loans. In addition to this, if net working capital deficit exits, all the amount of it should be included in the interest rate risk with the foresight for the need of new short-term finance.

Stock market position risk is a risk that a company may be exposed to due to capital value impairment of the stocks that the company holds and the highest risk amount that the company may be exposed to will be as much as the total of securities portfolio.

Subsidiary risk may be associated with the value decrease in affiliates and subsidiaries that the company has. It is equal to the total of affiliate or subsidiary items and goodwill balance linked to such organizations.

\section{FINDINGS AND CONCLUSION}

The iron and steel sector has a significant impact on the level of economic development of countries due to technological improvement, high share in world trade, high employment capacity and a driving force for other sectors. Therefore, stronger economic structures of the enterprises in the sector as a whole is important both for the sector and the economy. The state of the economic structures of the enterprises can be determined by measuring financial performance. In this study, LCR and CAR calculations were made using the financial tables for the years of 2015-2016 belonging to 14 enterprises within the scope of iron and steel and basic metal industry index.

\footnotetext{
1 Profit distribution for banking sector is subject to BRSA approval within specific limits whereas profit distribution can be made at any moment for real sector. Hence, undistributed profits item should not be evaluated as a long-term source.
} 
Table 5: Results

\begin{tabular}{|c|l|c|c|}
\hline $\mathbf{N r}$. & BIST Code & LCR & CAR \\
\hline $\mathbf{1}$ & ASCEL & 8.4 & 44.46 \\
\hline $\mathbf{2}$ & BRSAN & 1.92 & 38.64 \\
\hline $\mathbf{3}$ & CELHA & 1.04 & 13.83 \\
\hline $\mathbf{4}$ & CEMTS & 8.01 & 54.43 \\
\hline $\mathbf{5}$ & ERBOS & 4.17 & 41.48 \\
\hline $\mathbf{6}$ & EREGL & 2.58 & 48.53 \\
\hline $\mathbf{7}$ & IZMDC & 0.64 & 9.62 \\
\hline $\mathbf{8}$ & $\begin{array}{l}\text { KRDMA, } \\
\text { KRDMB, } \\
\text { KRDMD }\end{array}$ & 1.47 & 27.48 \\
\hline $\mathbf{9}$ & OZBAL & 0.4 & -1.07 \\
\hline \multicolumn{2}{|c|}{ SAMPLE AVERAGE } & $\mathbf{3 . 1 8}$ & $\mathbf{3 0 . 8 2}$ \\
\hline
\end{tabular}

In conformity with the sector's structure and in line with our expectation, LCR rates were found to vary between 0.4-8.4 The sector average is 3.18. Taking into account that; LCR is a liquidity obligation designed for increasing the resistance of banks against adverse shocks, it can be stated that our sample hold high quality liquid assets at sufficient amount to meet immediate and severe cash outflows for at least 30 days. When CAR results are considered, we see that the sector average value is $30.82 \%$. On the other hand, CAR take values between $54.43 \%$ and-1.07\% (negative for single firm). The single negative result is from Ozbal Celik, whose past year losses in equities is big (average CAR is 33\% except Ozbal Celik) The biggest difference results from operational risks which is a sub-item of SYR. Since basic indicator approach that we used in the operational risk calculation is based on revenue, its value increases as the revenue increases. More accurate calculations on trade recieveables and operational risk can be made on company basis whether the database is developed in this scope.

\section{REFERENCES}

BRSA, (2014). Regulation on Measurement and Assessment of Liquidity Adequacy of Banks, https://www.bddk.org.tr/WebSitesi/turkce/Mevzuat/Bankacilik_Kanununa_Iliskin_Duzenlemeler/12930likidite_yonetmeligi_28_2_2017.p df.

Turkmen, C., Turkmen, B., (2016). Adapting the Basel III Regulations to Real Sector Firms; An Attempt on Retail Sector, pp:104-111, Cambridge Scholars Publishing, ISBN: 978-1-4438-1704-2

Türkiye Cumhuriyeti Ekonomi Bakanlığı, (2016). Demir-Çelik, Demir-Çelikten Eşya Sektörü, İhracat Genel Müdürlüğü Maden, Metal ve Orman Ürünleri Daire Başkanlığı, Ankara.

WSA, (2017). World Steel in Figures 2016. ISBN 978-2-930069-87-6. 